\title{
Changes in soluble amino acid composition during Canavalia ensiformis development: responses to nitrogen deficiency
}

\author{
Liliane Santos Camargos • Leandro Ferreira Aguiar • Lucas Anjos Souza • \\ Gilberto Costa Justino - Ricardo Antunes Azevedo
}

Received: 12 November 2014/ Accepted: 20 May 2015/Published online: 4 June 2015

(C) Brazilian Society of Plant Physiology 2015

\begin{abstract}
A limited number of studies focusing nitrogen metabolism have been carried out with plants from Cerrado, the second largest biome of Brazil. Canavalia ensiformes is a legume native from Cerrado and is considered an important forage crop that contributes to soil nitrogen $(\mathrm{N})$ improvement. There are few studies related to amino acid metabolism and growth capacity under nitrogen deficiency for this plant species. Therefore, the objective of this work was to study the profile of soluble amino acids during
\end{abstract}

L. S. Camargos $(\bowtie)$

Departamento de Biologia e Zootecnia, Faculdade de Engenharia de Ilha Solteira, Universidade Estadual Paulista (UNESP), Ilha Solteira, SP, Brazil

e-mail: camargos@bio.feis.unesp.br

\section{F. Aguiar}

Departamento de Ciências Naturais, Universidade Federal de Mato Grosso do Sul, Campus de Três Lagoas,

Três Lagoas, MS, Brazil

L. A. Souza

Centro de Energia Nuclear na Agricultura - CENA/USP, Piracicaba, SP, Brazil

G. C. Justino

Instituto de Ciências Biológicas e da Saúde, Setor de Botânica, Universidade Federal de Alagoas, Maceió, AL, Brazil

\section{R. A. Azevedo}

Departamento de Genética, Escola Superior de

Agricultura Luiz de Queiroz, Universidade de São Paulo, Piracicaba, SP, Brazil the growth cycle (from vegetative to the reproductive stage) of Canavalia ensiformis. Major changes in the concentration and composition of soluble amino acids at the beginning of the reproductive stage were observed indicating important alterations in amino acids metabolism. The data revealed that $\mathrm{N}$-stress conditions led to increased aspartate and decreased asparagine contents in most organs and developmental stages of $C$. ensiformis. A pronounced increase in glutamate concentration during $\mathrm{N}$-stress was also detected. Glutamine, alanine, GABA, threonine, histidine, arginine and glycine metabolisms were probably impaired by $\mathrm{N}$ deficiency, which was dependent upon plant developmental stage. The effect of nitrate presence or absence on amino acids metabolism in $C$. ensiformis is discussed.

Keywords Amino acids - Leguminous - Nitrate · $\mathrm{N}$-stress

\section{Introduction}

Cerrado is the second largest Biome of Brazil accounting for about $25 \%$ of Brazilian land severely affected by degradation and deforestation (Klink and Machado 2005; Ribeiro et al. 2011). Studies focusing on the physiology of the plants growing on Cerrado conditions such as low availability of nitrogen $(\mathrm{N})$ are scarce. $\mathrm{N}$ is one of the most essential nutrients required for all living organisms and is considered a limiting 
factor for plant growth and development around the world. $\mathrm{N}$ is present in low concentrations in Cerrado regions, which makes the plant species from Cerrado interesting biological models to understand how these plants cope with this situation. In addition, little is known about the characteristic of $\mathrm{N}$ use efficiency by tropical plants species since most experiments has been conducted in temperate ecosystems (Aidar et al. 2003; Omena-Garcia et al. 2011). It is essential to understand the physiology of tropical plants since these biomes are constantly suffering anthropogenic impacts, which expose plants to new environmental conditions and potential impact on the $\mathrm{N}$ cycle.

Besides the high amount of $\mathrm{N}_{2}$ in the atmosphere, $\mathrm{N}$ is considered the major limiting nutrient for plant growth and development (Lea and Azevedo 2006, 2007; Andrews et al. 2009). Therefore, plant species growing on $\mathrm{N}$-poor soils have developed sensitive and selective systems for $\mathrm{N}$ uptake and transport (Williams and Miller 2001; Medici et al. 2003). Additionally, plants have developed a very efficient regulatory network in which carbon and nitrogen assimilations are linked in order to keep the balance of carbon/ nitrogen for optimum plant growth (Tischner 2000).

There are several forms of available $\mathrm{N}$ that can be used by plants species but which depend upon genesis and properties. In addition to ammonium and nitrate, $\mathrm{N}$ can also be found in soils as peptides, urea and purines (Lea and Azevedo 2006). Ammonium is usually found under special conditions such as low aeration, acid $\mathrm{pH}$ or high phenols concentrations in the soil. After organic matter decomposition by soil bacteria, ammonium is quickly taken up by plant roots (Hayden et al. 2010). However, nitrate is the most common form of available $\mathrm{N}$ in soils (Medici et al. 2004a, b).

Despite the high concentration of atmospheric $\mathrm{N}_{2}$, only a fraction of plant species is able to assimilate it because some plant species form an association with some nitrogen fixing bacteria. Some prokaryotic microorganisms or soil bacteria have developed a unique biochemical mechanism that allow them to reduce $\mathrm{N}_{2}$ to ammonia. Many of these microorganisms are able to associate symbiotically with other organisms, but leguminous is the only group of higher plants that have developed a wide symbiotic association (Fabra et al. 2010; Ling et al. 2013). The direct uptake of ammonium from the soil by the roots, as final product of nitrate assimilation or nitrogenase activity, is rapidly assimilated by the GS/GOGAT cycle, glutamine synthetase (GS, EC 6.3.1.2), glutamine oxoglutarate aminotransferase or simply glutamate synthase (GOGAT, EC 1.4.7.1) (Lea et al. 2007). After assimilation, the excess of amino acids can be exported from the leaves to the root through the phloem, while in roots the inverse route through the xylem takes place (Lohaus 1998).

Amino acid transport and metabolism are linked to environmental changes (Tsai et al. 2003). In fact, waterlogging and N-stress alters the level of amino acid in the xylem sap (Amarante et al. 2006; Justino and Sodek 2013). Similarly, organic N transport has been shown to be altered by seasonal changes in Piptadenia gonoacantha, Guapira opposita, Schizolobium parahyba and other tropical trees (Aidar et al. 2003). In this way, the amount of organic compounds can indicate the internal $\mathrm{N}$ status and the pool of these organic $\mathrm{N}$ compounds can indicate the survival strategies probably used by the species to deal with abiotic changes depending on the $\mathrm{N}$ levels in soils, apart from its role in the regulation of plant metabolism and nutritional aspects (Brennecke et al. 1996).

Considering that Canavalia ensiformes is an important crop plant species used as forage as well as for green manure due to its capacity for $\mathrm{N}$ fixation and that this plant is typically from Cerrado, the main objective of this study was to investigate how $\mathrm{N}$ metabolism works in contrasting situations of $\mathrm{N}$ availability by analyzing the amino acids profile in different tissues during the plant life cycle. Our expectative is that eventual changes in amino acids profile may indicate the $\mathrm{N}$ source that is used by the plant according to the environmental situation that it is subjected to.

\section{Materials and methods}

\subsection{Experimental design}

Commercial seeds of Canavalia ensiformis (L.) D.C. (jack bean) provided by Piraí Sementes (Piracicaba, SP, Brazil) were germinated in filter paper rolls with the bottom immersed in distilled-deionized water for 7-10 days in a growth chamber at $25^{\circ} \mathrm{C}$. At the end of this period, the plantlets were transferred to $4 \mathrm{~L}$ pots in a hydroponic system with continuous aeration and maintained in a greenhouse at temperatures ranging 
from 25 to $30{ }^{\circ} \mathrm{C}$ and kept for 100 days continuous supplied with Hoagland's nutritive solution (Hoagland and Arnon 1950) containing $7.5 \mathrm{mM}$ nitrate $\left(\mathrm{T}_{1}\right)$ and without nitrate $\left(\mathrm{T}_{2}\right)$ as described by Camargos et al. (2006). Three biological replicates for each developmental stage [vegetative (S1) and onset of flowering (S2)] were used. Roots, leaves and stems were collected and placed directly into liquid nitrogen and stored at $-80{ }^{\circ} \mathrm{C}$ for further analyses.

\subsection{Amino acids extraction and quantification}

Amino acids were extracted from the plant tissues by homogenization of $1 \mathrm{~g}$ fresh weight tissue with $10 \mathrm{~mL}$ of MCW (methanol/chloroform/water-12/5/3 v/vBielski and Turner 1966) in a Polytron ultrasonic homogenizer. After centrifugation at $800 \times g$, the supernatant (4 vol) was mixed with chloroform $(1 \mathrm{vol})$ followed by water $(1.5 \mathrm{vol})$ and the mixture shaken vigorously in a separating funnel. After phase separation the upper aqueous phase was recovered and used for analysis.

The amino acids contents were determined by the ninhydrin method by adding citrate buffer $(0.2 \mathrm{M}, \mathrm{pH}$ $5.0)$, ninhydrin $(5 \%)$, potassium cyanide $(0.001 \mathrm{M})$, and ethanol $(60 \%)$ to the samples (Yemm and Cocking 1955).

\subsection{Amino acids analysis by reverse-phase HPLC}

Soluble amino acids were separated and analyzed by reverse-phase HPLC as their $o$-phthaldialdehyde (OPA) derivatives, based on the method described by Jarret et al. (1986) and optimized by Azevedo et al. (2004). A Spherisorb ODS-2 column $(5 \mu \mathrm{m}$, $4 \times 250 \mathrm{~mm}$ ) was used and eluted at $0.8 \mathrm{~mL} \mathrm{~min}^{-1}$ with a linear gradient formed by solutions of $65 \%$ methanol and phosphate buffer $\mathrm{pH} 7.25(50 \mathrm{mM}$ sodium acetate, $50 \mathrm{mM}$ disodium phosphate, $1.5 \mathrm{~mL}$ acetic acid, $20 \mathrm{~mL}$ tetrahydrofuran, $20 \mathrm{~mL}$ methanol in $1 \mathrm{~L}$ of water). The gradient increased the proportion of $65 \%$ methanol from 20 to $60 \%$ between 0 and $25 \mathrm{~min}, 60$ to $75 \%$ from 25 to $31 \mathrm{~min}$, and 75 to $100 \%$ from 31 to $50 \mathrm{~min}$. The column effluent was monitored by a Shimadzu fluorescence detector (model RF350) operating with and excitation wavelength of $250 \mathrm{~nm}$ and an emission wavelength of $480 \mathrm{~nm}$. The amino acids proline and cysteine, which do not form an OPA derivative, could not be determined and therefore were excluded.

\subsection{Statistical analysis}

The data for the same parameters and at the same developmental stage were submitted to analysis of variance and the means were compared by the Tukey's test at $5 \%$ of significance.

\section{Results}

During the life cycle of $C$. ensiformis the dry weight was higher in plants cultivated in complete Hoagland nutritive solution (T1) when compared to plants cultivated in the absence of nitrate (T2) (Table 1). The total soluble amino acids content was higher in $\mathrm{T} 1$ than in $\mathrm{T} 2$ for all tissues and in both developmental stages studied (Table 2). Glutamate and aspartate contents were equally high in $\mathrm{T} 1$ and $\mathrm{T} 2$ leaves in vegetative stage (S1), whereas asparagine was the main $\mathrm{N}$-containing compound found in the stems in both $\mathrm{T} 1$ and $\mathrm{T} 2$ treatments (Tables 3,4 ).

Similarly, the same amino acid pattern was observed in the root system, although the content of asparagine was higher than $90 \mathrm{~mol} \%$ in stems and roots in $\mathrm{T} 1$ in $\mathrm{S} 1$ stage, whereas aspartate and glutamate were shown to be decreased. In S1 stage, asparagine represented $54 \%$ of the total soluble amino acid pool in stems in $\mathrm{T} 2$; this content of asparagine was shown to be decreased in $\mathrm{T} 2$ in flowering stage (S2), whereas aspartate and glutamate contents were increased in S2 stage. Canavanine was the predominant amino acid in the root system of the N-stressed plants (T2) during S1.

Table 1 Dry weights (g) of $C$. ensiformis tissues during vegetative (S1) and flowering (S2) stages under $7.5 \mathrm{mM}$ nitrate presence (T1) or nitrate absence (T2)

\begin{tabular}{|c|c|c|c|c|c|c|}
\hline & \multicolumn{2}{|l|}{ Leaf } & \multicolumn{2}{|l|}{ Stem } & \multicolumn{2}{|l|}{ Root } \\
\hline & $\mathrm{T} 1$ & $\mathrm{~T} 2$ & $\mathrm{~T} 1$ & $\mathrm{~T} 2$ & $\mathrm{~T} 1$ & $\mathrm{~T} 2$ \\
\hline $\mathrm{S} 1$ & $4.29 \mathrm{a}$ & $1.26 \mathrm{~b}$ & $2.61 \mathrm{a}$ & $0.86 b$ & $1.39 \mathrm{a}$ & $0.82 b$ \\
\hline $\mathrm{S} 2$ & $24.17 \mathrm{a}$ & $1.63 b$ & $11.52 \mathrm{a}$ & $1.62 b$ & $7.02 \mathrm{a}$ & $1.27 \mathrm{~b}$ \\
\hline
\end{tabular}

Means followed by different letters differ between nitrogen treatments, for the same plant organ and development stage, at $5 \%$ probability level according to Tukey test 
Table 2 Amino acids concentration $\left(\mu \mathrm{mol} \mathrm{g}^{-1}\right)$ in $C$. ensiformis tissues during vegetative (S1) and flowering (S2) stages under $7.5 \mathrm{mM}$ nitrate presence (T1) or nitrate absence (T2)

\begin{tabular}{|c|c|c|c|c|c|c|}
\hline & \multicolumn{2}{|l|}{ Leaf } & \multicolumn{2}{|l|}{ Stem } & \multicolumn{2}{|l|}{ Roots } \\
\hline & $\mathrm{T} 1$ & $\mathrm{~T} 2$ & $\mathrm{~T} 1$ & $\mathrm{~T} 2$ & $\mathrm{~T} 1$ & $\mathrm{~T} 2$ \\
\hline $\mathrm{S} 1$ & $15.73 a$ & $6.11 b$ & $41.12 \mathrm{a}$ & $19.55 b$ & $27.9 \mathrm{a}$ & $10.51 \mathrm{~b}$ \\
\hline $\mathrm{S} 2$ & $7.62 \mathrm{a}$ & $1.41 \mathrm{~b}$ & $7.49 a$ & $2.85 b$ & $9.84 \mathrm{a}$ & $0.71 b$ \\
\hline
\end{tabular}

Means followed by different letters differ between nitrogen treatments, for the same plant organ and development stage, at $5 \%$ probability level according to Tukey test

At S2 stage the composition of amino acids in all tissues was different when compared to S1 stage (Tables 3, 4). Leucine was the most representative soluble amino acid in leaves of plants treated with nitrate (T1), accounting to $48 \%$ of total soluble amino acid pool. GABA accounted for the second largest pool in leaves (14\%), but was not observed in stems or roots (Table 4). Moreover, glutamate and aspartate decreased while histidine, threonine and arginine contents increased in leaves (S2). Interestingly, asparagine increased whereas glutamine was inversely decreased in leaves and stems during S2 when compared to S1. Aspartate and glutamate were decreased in $\mathrm{T} 1$ but were higher in T2 in S2. However, differently from stems, in roots increased concentrations of aspartate and glutamate were observed in T1.

\section{Discussion}

The data obtained for $C$. ensiformis under the conditions tested in this work revealed that the responses to $\mathrm{N}$-stress may involve changes in amino acid metabolism. Major changes in the soluble amino acid pool of leaves, stems and roots in C. ensiformis under $\mathrm{N}$-deficiency were observed. In fact, the internal pool of soluble amino acids in plant tissues indicates the $\mathrm{N}$ status by providing a signal that can regulate nitrate

Table 3 Quantitative analysis of soluble amino acids (mol\% \pm S.E) in tissues of C. ensiformis during vegetative stage (S1)

\begin{tabular}{|c|c|c|c|c|c|c|}
\hline \multirow[t]{2}{*}{ Amino acids } & \multicolumn{2}{|l|}{ Leaf } & \multicolumn{2}{|l|}{ Stem } & \multicolumn{2}{|l|}{ Roots } \\
\hline & $\mathrm{T} 1$ & $\mathrm{~T} 2$ & $\mathrm{~T} 1$ & $\mathrm{~T} 2$ & $\mathrm{~T} 1$ & $\mathrm{~T} 2$ \\
\hline Aspartate & $39.04 \pm 0.01$ & $15.22 \pm 0.02$ & $1.54 \pm 0.02$ & $20.29 \pm 0.02$ & $1.49 \pm 0.01$ & $13.44 \pm 0.02$ \\
\hline Glutamate & $18.72 \pm 0.02$ & $60.30 \pm 0.03$ & ND & $0.46 \pm 0.01$ & $5.56 \pm 0.01$ & $6.45 \pm 0.01$ \\
\hline Asparagine & $12.84 \pm 0.01$ & ND & $96.91 \pm 0.02$ & $54.61 \pm 0.01$ & $90.11 \pm 0.03$ & $2.90 \pm 0.02$ \\
\hline Serine & ND & ND & ND & ND & ND & $11.07 \pm 0.01$ \\
\hline Histidine & ND & ND & ND & ND & ND & ND \\
\hline Glutamine & ND & ND & ND & ND & ND & ND \\
\hline Canavanine & ND & ND & ND & ND & ND & $65.74 \pm 0.03$ \\
\hline Glycine & ND & ND & ND & ND & ND & ND \\
\hline Threonine & ND & ND & ND & $6.78 \pm 0.01$ & $2.83 \pm 0.02$ & ND \\
\hline Arginine & $29.38 \pm 0.02$ & ND & ND & ND & ND & ND \\
\hline Alanine & ND & ND & ND & ND & ND & ND \\
\hline GABA & ND & ND & ND & ND & ND & ND \\
\hline Tyrosine & ND & $9.85 \pm 0.01$ & ND & ND & ND & ND \\
\hline Metionine & ND & $14.63 \pm 0.01$ & ND & $1.38 \pm 0.02$ & ND & $0.39 \pm 0.01$ \\
\hline Valine & ND & ND & $1.54 \pm 0.02$ & ND & ND & ND \\
\hline Phenylalanine & ND & ND & ND & $16.47 \pm 0.02$ & ND & ND \\
\hline Isoleucine & ND & ND & ND & ND & ND & ND \\
\hline Leucine & ND & ND & ND & ND & ND & ND \\
\hline Lysine & ND & ND & ND & ND & ND & ND \\
\hline
\end{tabular}

T1: plants cultivated with $7.5 \mathrm{mM}$ of nitrate, T2: plants cultivated without nitrate

$N D$ not detected/below detection limits 
Table 4 Quantitative analysis of soluble amino acids (mol\% \pm S.E.) in tissues of C. ensiformis during flowering stage (S2)

\begin{tabular}{|c|c|c|c|c|c|c|}
\hline \multirow[t]{2}{*}{ Amino acids } & \multicolumn{2}{|l|}{ Leaf } & \multicolumn{2}{|l|}{ Stem } & \multicolumn{2}{|l|}{ Roots } \\
\hline & $\mathrm{T} 1$ & $\mathrm{~T} 2$ & $\mathrm{~T} 1$ & $\mathrm{~T} 2$ & $\mathrm{~T} 1$ & $\mathrm{~T} 2$ \\
\hline Aspartate & $1.56 \pm 0.01$ & $40.73 \pm 0.02$ & $3.20 \pm 0.03$ & $28.40 \pm 0.01$ & $2.02 \pm 0.01$ & $24.22 \pm 0.02$ \\
\hline Glutamate & $2.36 \pm 0.01$ & $26.62 \pm 0.02$ & $1.32 \pm 0.02$ & $7.90 \pm 0.01$ & $3.59 \pm 0.01$ & $6.23 \pm 0.01$ \\
\hline Asparagine & $8.62 \pm 0.02$ & $4.90 \pm 0.03$ & $62.31 \pm 0.01$ & $17.38 \pm 0.02$ & $24.40 \pm 0.01$ & $6.23 \pm 0.02$ \\
\hline Serine & $0.98 \pm 0.01$ & $6.65 \pm 0.01$ & $0.94 \pm 0.02$ & $4.27 \pm 0.02$ & ND & $10.88 \pm 0.02$ \\
\hline Histidine & $2.85 \pm 0.01$ & $4.59 \pm 0.02$ & $1.81 \pm 0.01$ & $0.66 \pm 0.02$ & $5.35 \pm 0.01$ & $43.49 \pm 0.03$ \\
\hline Glutamine & $1.06 \pm 0.02$ & $12.19 \pm 0.01$ & $0.17 \pm 0.01$ & $35.47 \pm 0.03$ & $9.16 \pm 0.02$ & $0.98 \pm 0.01$ \\
\hline Canavanine & $0.88 \pm 0.01$ & $2.63 \pm 0.02$ & $0.51 \pm 0.01$ & ND & $1.40 \pm 0.03$ & $1.11 \pm 0.01$ \\
\hline Glycine & $1.31 \pm 0.01$ & ND & $1.17 \pm 0.02$ & ND & $3.93 \pm 0.02$ & ND \\
\hline Threonine & $0.06 \pm 0.01$ & ND & ND & ND & ND & ND \\
\hline Arginine & $9.93 \pm 0.03$ & ND & $6.77 \pm 0.01$ & ND & $30.78 \pm 0.02$ & ND \\
\hline Alanine & $0.32 \pm 0.01$ & ND & $5.48 \pm 0.02$ & ND & $6.32 \pm 0.01$ & ND \\
\hline GABA & $13.97 \pm 0.02$ & ND & ND & ND & ND & ND \\
\hline Tyrosine & ND & ND & ND & ND & $2.53 \pm 0.02$ & ND \\
\hline Metionine & $0.01 \pm 0.01$ & $1.67 \pm 0.01$ & $1.05 \pm 0.01$ & $4.09 \pm 0.02$ & $5.80 \pm 0.02$ & $6.83 \pm 0.02$ \\
\hline Valine & $1.34 \pm 0.02$ & ND & $2.18 \pm 0.03$ & $0.94 \pm 0.01$ & $3.03 \pm 0.01$ & ND \\
\hline Phenylalanine & $2.42 \pm 0.01$ & ND & $1.56 \pm 0.01$ & $0.45 \pm 0.01$ & $1.05 \pm 0.02$ & ND \\
\hline Isoleucine & $3.45 \pm 0.02$ & ND & $1.47 \pm 0.01$ & $0.40 \pm 0.01$ & $0.62 \pm 0.01$ & ND \\
\hline Leucine & $48.49 \pm 0.03$ & ND & $10.05 \pm 0.02$ & ND & ND & ND \\
\hline Lysine & $0,35 \pm 0,02$ & ND & ND & ND & ND & ND \\
\hline
\end{tabular}

T1: plants cultivated with $7.5 \mathrm{mM}$ of nitrate, T2: plants cultivated without nitrate

$N D$ not detected/below detection limits

uptake by the plant root system (Miller et al. 2008; Fan et al. 2009). Therefore, environmental changes may impair metabolism and the exportation of $\mathrm{N}$ from the roots to the shoots (Justino and Sodek 2013; Lanza et al. 2014). For instance, reduction of glutamine and increase of alanine in xylem sap were observed in nodulated soybean plants under waterlogging stress (Amarante et al. 2006; Justino and Sodek 2013). $\mathrm{N}$-stressed soybean plants exhibited altered $\mathrm{N}$ concentration and the distribution of $\mathrm{N}$ compounds transported to the shoots might reflect changes in amino acids metabolism in the roots (Lima and Sodek 2003; Amarante et al. 2006). In C. ensiformis the amount of total soluble amino acids was significantly different between vegetative (S1) and flowering (S2) stages and higher contents of aspartate and glutamate were observed in leaves of $\mathrm{T} 1 \quad(7.5 \mathrm{mM}$ nitrate presence). Such results suggest that nitrate reduction takes place preferably in the shoot, confirming the previous report by Camargos et al. (2006), whereas asparagine is an important $\mathrm{N}$-transport compound in major higher plants. Moreover, Lohaus (1998) reported that the reduction of nitrate was altered in response to the levels of soluble amino acids in sugar beet.

Glutamate, aspartate and arginine are clearly the major forms of soluble amino acids accumulated in leaves in $\mathrm{T} 1$ ( $7.5 \mathrm{mM}$ nitrate presence) during vegetative stage (S1). As observed in this study (Table 3), glutamate, glutamine and aspartate are the most abundant soluble amino acids encountered in leaves of plant species that reduce nitrate primarily in the shoot such as barley, spinach and potato, whilst asparagine is less abundant (Lohaus 1998; Camargos et al. 2006). However, in stems, asparagine was the predominant amino acid in the two treatments applied, for instance in S1 stage of T1 plants, whereas low contents of aspartate and glutamate were detected. It has been reported in maize that the increase in the asparagine content decreases the concentration of glutamate, alanine and aspartate, and only asparagine may represent more than $45 \%$ of the 
total soluble amino acids transported (Lohaus 1998). Atkins et al. (1983) reported that in leaves of Lupinus albus, during the developmental cycle, asparagine accounted to $89-93 \%$ of the total of soluble amino acid pool in the leaf tissue. Such high asparagine concentration was observed in the roots of $C$. ensiformis in S1 stage, accounting to $90 \%$ in $\mathrm{T} 1$, which may be explained by the low concentration of aspartate and glutamate, since these two amino acids contribute to the synthesis of asparagine.

Asparagine accumulation decreased and aspartate and glutamate contents increased during $\mathrm{N}$-stress treatment (T2). On the other hand, as leaf fresh weight was reduced by $\mathrm{N}$-stress, plants transported and accumulated $\mathrm{N}$ as canavanine (Table 4) possibly in order to save carbon, since this amino acid has low C:N ratios (Corbesier et al. 2001). Apparently, in order to maintain $\mathrm{N}$ transport in plants that exhibited leaf biomass reduced by $\mathrm{N}$-deficiency, plants transported and accumulated specific amino acids, probably compensating for photosynthetic limitations.

Total amino acid pool increased in all tissues of flowering plants (S2) with a marked increase in glutamine, followed by glycine and serine. Stitt et al. (2002) reported that asparagine acts as donor of amine group for the synthesis of amino acids in the photorespiratory cycle, which appears to explain the high contents of serine and glycine in T2 and T1 of S2, respectively, when compared to asparagine as observed in C. ensiformis. In sorghum, glycine increased during the vegetative and reproductive stages when the plants were supplied with nitrate (Neto et al. 2009). The leucine content was predominant among all amino acids in $\mathrm{T} 1$ (7.5 $\mathrm{mM}$ nitrate presence) accounting to about half of the total soluble amino acid pool, which might be explained due to altered regulation of the biosynthetic pathways at the developmental stages of plant growth (Noctor et al. (2002). Comparing the data in Tables 1 and 2 some differences can be observed, but more studies of the specific alterations to the leucine synthetic pathway need to be addressed to understand and the changes observed in this study.

The glutamine increase observed in leaves at the flowering stage suggests that this amino acid can act at the beginning of the pathway that promotes the transition to the flowering stage (Corbesier et al. 2001; Camargos et al. 2006). Corbesier et al. (2001) working with Arabidopsis thaliana, reported that the composition of the leaf exudate was also changed during the transition to the flowering stage, with an increased leaf export of glutamine in LD (long day plants) and of asparagine in DSD (displaced short day). GABA ( $\gamma$-amino butyric acid) concentration was high in leaves of $\mathrm{T} 1$ (7.5 mM nitrate presence), and according to Bown and Shelp (1997) this non-proteic amino acid plays a role in plant development as well as a temporary $\mathrm{N}$ storage compound. GABA is synthesized in the cytosol through the irreversible decarboxylation of glutamate by GAD (glutamate decarboxylase), a process that is considered important as energy source due to the generation of succinate, which integrates the Krebs'cycle (Shelp et al. 1999). The decrease of glutamate and increase of GABA in T1 during the flowering stage (Table 4) suggest that the pool of glutamate is being directed to supply the energy demand during flowering. As GABA synthesis is mainly controlled by GAD, it is possible that this enzyme is regulated according to the plant development and $\mathrm{N}$ status of $C$. ensiformis. Chen et al. (1994) reported high levels of GAD (glutamate decarboxylase) expression during flowering and germination of petunia plants, which supports our findings since we could not detect GABA ( $\gamma$-amino butyric acid) in any organ in vegetative stage (S1) although high levels of glutamate were observed in leaves.

In all plant tissues analyzed (leaves, roots and stems) at the flowering stage (S2), an increase in the level of aspartate in relation to asparagine was observed (Table 4). Lima and Sodek (2003) demonstrated that alterations in the supply of $\mathrm{N}$ alter the aspartate and asparagine ratios in soybean. In contrast, histidine and arginine exhibited lower contents in the two treatments when compared to the concentrations of aspartate and glutamate in both developmental stages. Based on these results it is possible that an increase in histidine and arginine occurred, instead of those belonging to the aspartate pathway (aspartate, methionine, isoleucine and lysine) (Azevedo et al. 1997; Azevedo and Arruda 2010). Additionally, arginine, as the biosynthetic precursor of polyamines, a class of compounds related to plant development and to some extent also related to abiotic stress tolerance, suggest the regulation of arginine biosynthesis to support the synthesis of polyamines that can be further transported and degraded to provide $\mathrm{N}$ to other tissues (Moschou et al. 2012).

In roots, the increase in aspartate and glutamate concentrations were also observed when compared to 
stems in T1 (Table 4). In a similar manner, Lohaus (1998) reported that glutamine was shown to be present in high concentrations in maize, while the asparagine content was decreased. In C. ensiformis, $\mathrm{N}$ deficiency decreased asparagine in contrast to what was observed in soybean (Antunes et al. 2008), which exhibited increased asparagine, but not glutamine. In this work, histidine, arginine and threonine concentrations were shown to be higher at flowering (S2) in relation to vegetative stage (S1), whilst glycine, which was not detected in S1, was found in S2 during the flowering stage (Table 4). Camargos et al. (2004) observed that glycine concentrations were higher in mature seeds in $C$. ensiformis, suggesting that an increase in the synthesis of this amino acid at this developmental stage can be related to its accumulation in seeds.

Analysis of xylem sap exudate at the flowering stage (data not shown) in response to nitrate revealed that leucine was the preferred transported amino acid during this stage instead of glutamine. Amino acids from the xylem sap are useful indicators of responses by the assimilatory $\mathrm{N}$ processes in the root system (Amarante et al. 2006). Thus, alterations of glutamine levels appear to be related to the change in the site of nitrate reduction indicating that this mineral $\mathrm{N}$ source started to be reduced in the roots as previously proposed by Camargos et al. (2006). The fact that nitrate acts inhibiting flowering may explain the alteration in the preferential site of nitrate reduction according to the developmental stage (Corbesier et al. 2001; Canatto et al. 2014).

In $\mathrm{T} 1$ ( $7.5 \mathrm{mM}$ nitrate presence) of flowering stage (S2) high serine and glycine concentration were observed in the tissues analyzed, the latter found in larger concentrations when compared with T2 (absence of nitrate). The high concentration of leucine was accompanied by low glutamate concentration, which apparently indicates a preferential increase in leucine synthesis. On the other hand, leucine biosynthesis has not been well investigated, but there are indications that the inhibition of the synthesis of this amino acid may occur by feedback with micromolar concentrations of leucine (Coruzzi and Last 2000).

Quantitative alterations were clearly observed for the total soluble amino acid contents in leaves during the flowering stage (S2) with $\mathrm{T} 1 \quad(7.5 \mathrm{mM}$ nitrate presence) exhibiting significant increases when compared to absence of nitrate (Table 4). In roots, significant variation in the concentration of soluble amino acids were found in both treatments, T1 exhibiting the highest levels and T2 the lowest.

Asparagine values reduced in the tissues of plants under N-deficiency clearly indicated a markedly change in the aspartate/asparagine ratio in the tissues. Decrease in asparagine content in higher plants under $\mathrm{N}$-deficiency has been reported as observed for example in soybean and others legumes and nonlegumes plant species (Amarante et al. 2006). Moreover, decrease of asparagine synthetase activity of the nodules was also observed (Lima and Sodek 2003).

In conclusion, our data suggest that nitrate N-deficiency imposed several alterations in amino acid metabolism and these effects are related to increase and decrease of amino acids contents in C. ensiformis tissues supplied or not with nitrate, with alterations in aspartate/asparagine ratios under $\mathrm{N}$-deficiency. Additionally, the presence of soluble amino acids such as leucine, histidine, arginine, phenylalanine and canavanine suggest major changes in amino acid metabolism between developmental stages according to $\mathrm{N}$ supplementation or not.

Acknowledgments The authors acknowledge the support given to this work by the 'Fundação de Amparo a Pesquisa do Estado de São Paulo’ (FAPESP-Brazil).

\section{References}

Aidar MPM, Schmidt S, Moss G, Stewart GR, Joly CA (2003) Nitrogen use strategies of neotropical rainforest trees in threatened Atlantic forest. Plant Cell Environ 26:389-399. doi:10.1046/j.1365-3040.2003.00970.x

Amarante L, Lima JD, Sodek L (2006) Growth and stress conditions cause similar changes in xylem amino acids for different legume species. Environ Exp Bot 58:123-129. doi:10.1016/j.envexpbot.2005.07.002

Andrews M, Lea PJ, Raven JA, Azevedo RA (2009) Nitrogen use efficiency. 3. Nitrogen fixation: genes and costs. Ann Appl Biol 155:1-13. doi:10.1111/j.1744-7348.2009. 00338.x

Antunes F, Aguilar M, Pineda M, Sodek L (2008) Nitrogen stress and the expression of asparagine synthetase in roots and nodules of soybean (Glycine max). Physiol Plant 133:736-743. doi:10.1111/j.1399-3054.2008.01092.x

Atkins CA, Pate JS, Peoples MB, Joy KW (1983) Amino acid transport and metabolism in relation to the nitrogen economy of a legume leaf. Plant Physiol 71:841-848. doi:10. 1104/pp.71.4.841

Azevedo RA, Arruda P (2010) High lysine maize: the key discoveries that have made it possible. Amino Acids 39:979-989. doi:10.1007/s00726-010-0576-5 
Azevedo RA, Arruda P, Turner WL, Lea PJ (1997) The biosynthesis and metabolism of the aspartate derived amino acids. Phytochemistry 46:395-419. doi:10.1016/ S0031-9422(97)00319-1

Azevedo RA, Lea PJ, Damerval C, Landry J, Bellato CM, Meinhardt LW, Le Guilloux M, Delhaye S, Varisi VA, Gaziola SA, Gratão PL, Toro AA (2004) Regulation of lysine metabolism and endosperm protein synthesis by the opaque-5 and opaque-7 maize mutations. J Agric Food Chem 52:4865-4871. doi:10.1021/jf035422h

Bielski LR, Turner NA (1966) Separation and estimation of amino acids in crude plant extracts by thin-layer electrophoresis and chromatography. Anal Biochem 17:278-293. doi:10.1016/ 0003-2697(66)90206-5

Bown AW, Shelp BJ (1997) The metabolism and functions of gamma-aminobutyric acid. Plant Phys 115:1-5

Brennecke K, Neto AJS, Lugli J, Lea PJ, Azevedo RA (1996) Aspartate kinase in the maize mutants ASK1-LT19 and opaque-2. Phytochemistry 41:707-712. doi:10.1016/00319422(95)00634-6

Camargos LS, Aguiar LF, Azevedo RA (2004) Variation in the amino acid concentration during development of Canavalia ensiformis. Biol Plant 48:309-314. doi:10.1023/B: BIOP.0000033463.98440.db

Camargos LS, Aguiar LF, Azevedo RA (2006) Site of nitrate reduction in jack bean (Canavalia ensiformis) changes from leaf to root during development. N Z J Crop Hort 34:131-137. doi:10.1080/01140671.2006.9514397

Canatto RA, Aguiar LF, Justino GC, Souza LA, Camargos LS (2014) O nitrato influencia o metabolismo de compostos nitrogenados em calopogônio (Calopogonium mucunoides) ao longo do ciclo de vida. Biotemas 27:1-8. doi:10.5007/2175-7925.2014v27n1p1

Chen YL, Baum G, Fromm H (1994) The 58-kilodalton calmodulin binding glutamate descarboxylase is a ubiquitous protein in Petunia organs and its expression is developmentally regulated. Plant Physiol 106:1381-1387

Corbesier L, Havelange A, Lejeune P, Bernier G, Perilleux C (2001) N content of phloem and xylem exudates during the translation to flowering in Sinapis alba and Arabidopsis thaliana. Plant Cell Environ 24:367-375. doi:10.1046/j. 1365-3040.2001.00683.x

Coruzzi G, Last R (2000) Amino Acids. In: Buchanan B, Gruissem W, Jones R (eds) Biochemistry and molecular biology of plants, 1st edn. American Society of Plant Physiologists, Rockville, pp 358-410

Fabra A, Castro S, Taurian T, Angelini J, Ibanez F, Dardanelli M, Tonelli M, Bianucci E, Valetti L (2010) Interaction among Arachis hypogaea L. (peanut) and beneficial soil microorganisms: how much is it known? Crit Rev Microbiol 36:179-194. doi:10.3109/10408410903584863

Fan S, Lin C, Hsu P, Lin S, Tsay Y (2009) The Arabidopsis nitrate transporter NRT1.7, expressed in phloem, is responsible for source-to-sink remobilization of nitrate. Plant Cell 21:2750-2761. doi:10.1105/tpc.109.067603

Hayden HL, Drake J, Imhof M, Oxley APA, Norng S, Mele PM (2010) The abundance of nitrogen cycle genes amoA and nifH depends on land-uses and soil types in south-eastern Australia. Soil Biol Biochem 42:1774-1783. doi:10.1016/ j.soilbio.2010.06.015
Hoagland DR, Arnon DI (1950) The water culture method for growing plants without soil. Agricultural Experimental Station Bulletin, California

Jarret HW, Cooksy KD, Wllist T, Anderson JM (1986) The separation of 0 -phthalaldehyde derivatives of amino acids by reverse-phase chromatography on octylsilica column. Anal Biochem 153:189-198. doi:10.1016/0003-2697(86)90079-5

Justino GC, Sodek L (2013) Recovery of nitrogen fixation after short-term flooding of the nodulated root system of soybean. J Plant Physiol 170:235-241. doi:10.1016/j.jplph. 2012.10.006

Klink CA, Machado RB (2005) Conservation of the Brazilian Cerrado. Conserv Biol 19:707-713

Lanza LNM, Lanza DCF, Sodek L (2014) Utilization of $15 \mathrm{NO} 3$ - by nodulated soybean plants under conditions of root hypoxia. Physiol Mol Biol Plants 20:287-293. doi:10. 1007/s12298-014-0241-7

Lea PJ, Azevedo RA (2006) Nitrogen use efficiency. 1. Uptake of nitrogen from the soil. Ann Appl Biol 149:243-247. doi:10.1111/j.1744-7348.2006.00101.x

Lea PJ, Azevedo RA (2007) Nitrogen use efficiency. 2: Amino acid metabolism. Ann Appl Biol 151:269-275. doi:10. 1111/j.1744-7348.2007.00200.x

Lea PJ, Sodek L, Parry MAJ, Shewry R, Halford NG (2007) Asparagine in plants. Ann Appl Biol 150:1-26. doi:10. 1111/j.1744-7348.2006.00104.x

Lima JD, Sodek L (2003) N-stress alters aspartate and asparagine levels of xilem sap in soybean. Plant Sci 165:649-656. doi:10.1016/S0168-9452(03)00251-6

Ling J, Zheng H, Katzianer DS, Wang H, Zhong Z, Jun-Zhu J (2013) Applying reversible mutations of nodulation and nitrogen-fixation genes to study social cheating in Rhizobium etli-legume interaction. PLoS ONE 8:1-8

Lohaus G (1998) Transport of amino acids with special emphasis on the synthesis and transport of asparagine in the Illinois low protein and Illinois high protein strains of maize. Planta 205:181-188. doi:10.1007/s004250050310

Medici LO, Machado AT, Azevedo RA, Pimentel C (2003) Glutamine synthetase activity, relative water content and water potential in maize submitted to drought. Biol Plant 47:301-304. doi:10.1023/B:BIOP.0000022271.35778.17

Medici LO, Azevedo RA, Smith RJ, Lea PJ (2004a) The influence of nitrogen supply on antioxidant enzymes in plant roots. Funct Plant Biol 31:1-9. doi:10.1071/FP03130

Medici LO, Pereira MB, Lea PJ, Azevedo RA (2004b) Diallel analysis of maize lines with contrasting responses to applied nitrogen. J Agric Sci 142:535-541

Miller MN, Zebarth BJ, Dandie CE, Burton DL, Goyer C, Trevors JT (2008) Crop residue influence on denitrification, $\mathrm{N}_{2} \mathrm{O}$ emissions and denitrifier community abundance in soil. Soil Biol Biochem 40:2553-2562. doi:10.1016/j. soilbio.2008.06.024

Moschou PN, Wu J, Cona A, Tavladoraki P, Angelini R, Roubelakis-Angelakis KA (2012) The polyamines and their catabolic products are significant players in the turnover of nitrogenous molecules in plants. J Exp Bot 63:5003-5015. doi:10.1093/jxb/ers202

Neto CFO, Lobato AKS, Costa RCL, Maia WJMS, Santos-Filho BG, Alves GAR, Brinez B, Neves HKB, Lopes MJS, Cruz FJR (2009) Nitrogen compounds and enzyme activities in 
sorghum induced to water deficit during three stages. Plant Soil Environ 55:238-244

Noctor G, Novitskaya L, Lea PJ, Foyer CH (2002) Co-ordination of leaf minor amino acid contents in crop species: significance and interpretation. J Exp Bot 53:939-945. doi:10.1093/jexbot/53.370.939

Omena-Garcia RP, Justino GC, Sodek L, Gonçalves JFC (2011) Mineral nitrogen affects nodulation and amino acido transport in the Amazonian legume Inga edulis Mart. Int J Plant Physiol Biochemy 3:215-218

Ribeiro SC, Fehrmann L, Soares CPB, Jacovine LAG, Kleinn C, Gaspar RO (2011) Above- and belowground biomass in a Brazilian Cerrado. Forest Ecol Manag 262:491-499. doi:10.1016/j.foreco.2011.04.017

Shelp BJ, Bown AW, McLean MD (1999) Metabolism and functions of gamma-aminobutyric acid. Trends Plant Sci 4:446-452. doi:10.1016/S1360-1385(99)01486-7
Stitt M, Muller C, Matt P, Gibon Y, Carillo P, Morcuende R, Scheible W, Krapp A (2002) Steps towards an integrated view of nitrogen metabolism. J Exp Bot 53:959-970. doi:10.1093/jexbot/53.370.959

Tischner R (2000) Nitrate uptake and reduction in higher and lower plants. Plant Cell Environ 23:1005-1024. doi:10. 1046/j.1365-3040.2000.00595.x

Tsai YC, Hsu YT, Kao CH (2003) Proline accumulation induced by phosphinothricin in rice leaves. Biol Plant 46:317-320. doi:10.1023/A:1022835618494

Williams LE, Miller AJ (2001) Transporters responsible for the uptake and partitioning of nitrogenous solutes. Annu Rev Plant Physiol Plant Mol Biol 52:659-688. doi:10.1146/ annurev.arplant.52.1.659

Yemm HE, Cocking EC (1955) The determination of amino acids with ninhydrin. Analyst 80:209-213. doi:10.1039/ an9558000209 